Brit. F. industr. Med., 1966, 23, 240

\title{
Miscellanea
}

\section{Twins with Coal-workers' Pneumoconiosis}

\author{
J. E. M. HUTCHINSON
}

From the Pneumoconiosis Medical Panel, 81 St. Mary's Place, Newcastle upon Tyne

As the tuberculous hypothesis of coal-workers' progressive massive fibrosis (P.M.F.) is not so strongly held nowadays the possible importance of genetic factors should be explored. Twins with pneumoconiosis should provide helpful information. Details are given of two pairs of twins; one pair is considered to be monozygotic and the other dizygotic. Blood grouping, secretor state, and Rose Waaler reactions were carried out as the results may help in any comparison with twins with coal-workers' pneumoconiosis discovered elsewhere.

The brothers resemble each other in having a similar type of pneumoconiosis. The monozygotic pair have a relatively benign type of pneumoconiosis with early P.M.F. which has remained unchanged for eight years; the dizygotic pair show a nodular type of pneumoconiosis which has shown definite progression with an increase in the extent of P.M.F. As a younger brother of the dizygotic pair also has pneumoconiosis details are included.

Sluis-Cremer (1960) described a study of twin miners; out of 12 pairs examined one pair of identical twins was found who showed radiological evidence of silicosis.

For several years we have been interested in the possibility of there being a family pattern in coalworkers' pneumoconiosis. Over 200 families have been found in which two or more brothers have been diagnosed as having pneumoconiosis- 180 with two brothers; 40 with three brothers; four with four brothers; and two with five brothers.

Among them are two pairs of twins; one pair is considered to be monozygotic and the other pair dizygotic. As the dizygotic pair has a younger brother with pneumoconiosis details of him are also given.

\section{Monozygotic Twins}

These two brothers (referred to as $\mathrm{XI}_{1}$ and $\mathrm{X}_{2}$ ) aged 63 years, have worked at adjoining collieries, mostly on deputy work, for 30 years and were found to have pneumoconiosis in 1956 when they were 55 years old. Their pneumoconiosis has remained unchanged since (Figs. Ia, b; 2a, b). Both brothers have been operated on for repairs of bilateral inguinal

Received for publication January II, 1966. herniae. One of them ( $\left.\mathrm{X}_{2}\right)$ developed pneumonia after his operation in 1935 which probably accounts for the bilateral pleural changes on his chest radiograph and perhaps partly for the lower F.E.V.1.0 of 2.2 litres compared with his brother's 2.9 litres. $\mathrm{He}$ has smoked Io cigarettes daily since the age of 35 whereas his brother has never smoked.

As shown in Table I, XI has had a raised blood pressure at each examination but $\mathrm{X}_{2}$ had normal blood pressure readings until 1958 and then a rise occurred between 1958 and 1960 and his blood pressure has remained high since. XI had an operation for the removal of a cartilage from the right knee in 1960 and $X_{2}$ had a fracture of the right tibia in 1962 .

\section{Dizygotic Twins}

These twins ( $\mathrm{YI}_{\mathrm{I}}$ and $\mathrm{Y}_{2}$ ) are 54 years old and their younger brother $\left(\mathrm{Y}_{3}\right)$ is 52 years. All three brothers have worked at the same colliery and sometimes together on the same face. Their chest radiographs show a nodular type of pneumoconiosis and all three have shown some progression of the disease (Figs. 3, 4, and 5). The youngest brother $\left(\mathrm{Y}_{3}\right)$ has the most extensive and more rapidly progressive pneumoconiosis (Figs. 5a, b) and now has sputum positive for tubercle bacilli. Of the dizygotic twins, 


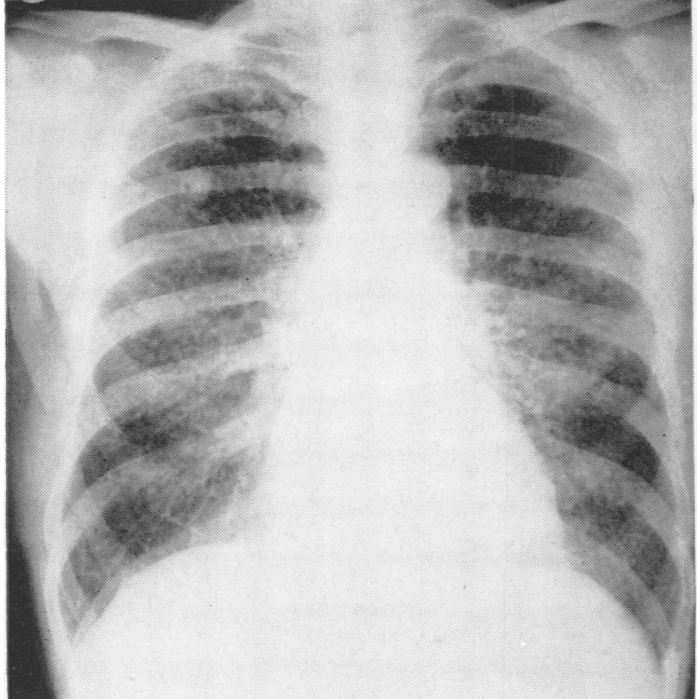

FIG. I. Chest radiographs twin brother $\mathrm{XI}_{1}$, (a) 1958;

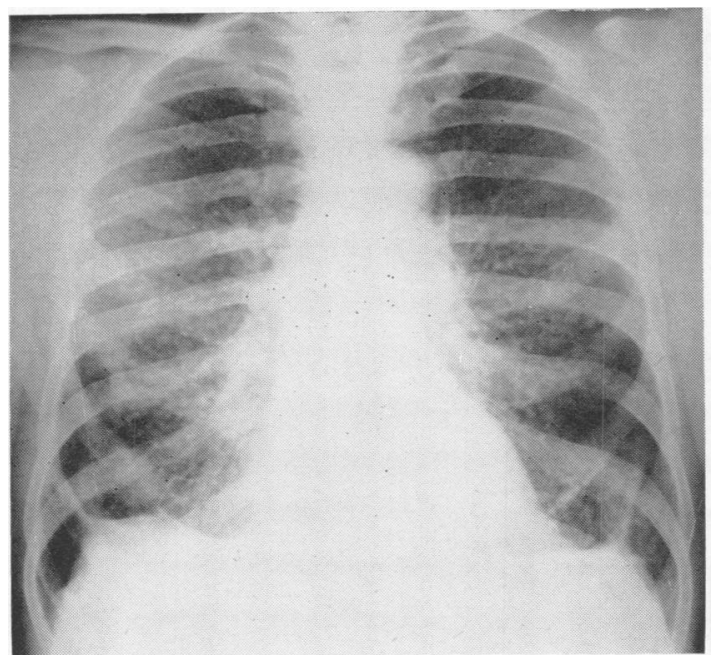

FIG. 2. Chest radiographs twin brother X2, (a) I958;

one (YI) was discovered in 1954 and has probably had the least exposure to dust. Details are given in Table II.

Blood grouping and tests of the secretor state using gorse seed extract were carried out. The Rose Waaler reaction was also determined since Caplan, Payne, and Withey (1962) showed that there was a higher incidence of positive results among subjects with the nodular type of pneumoconiosis. All the

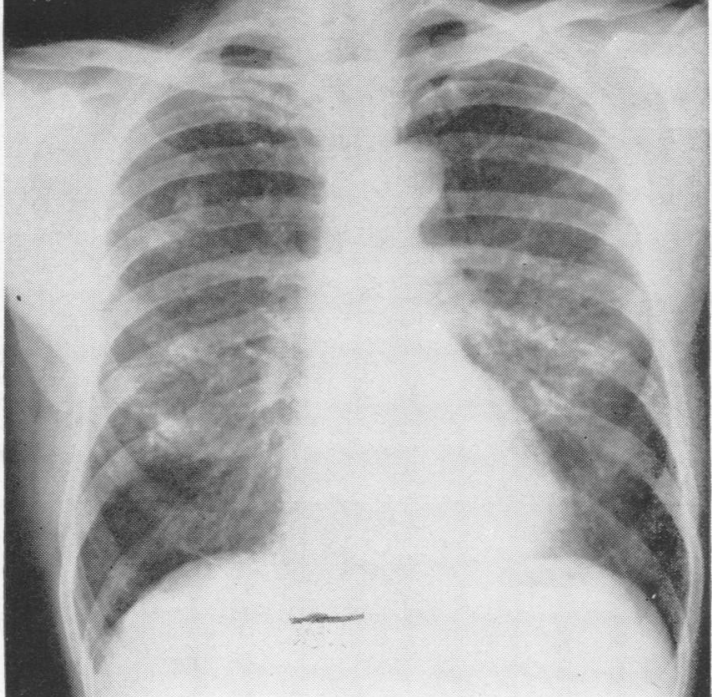

(b) 1962.

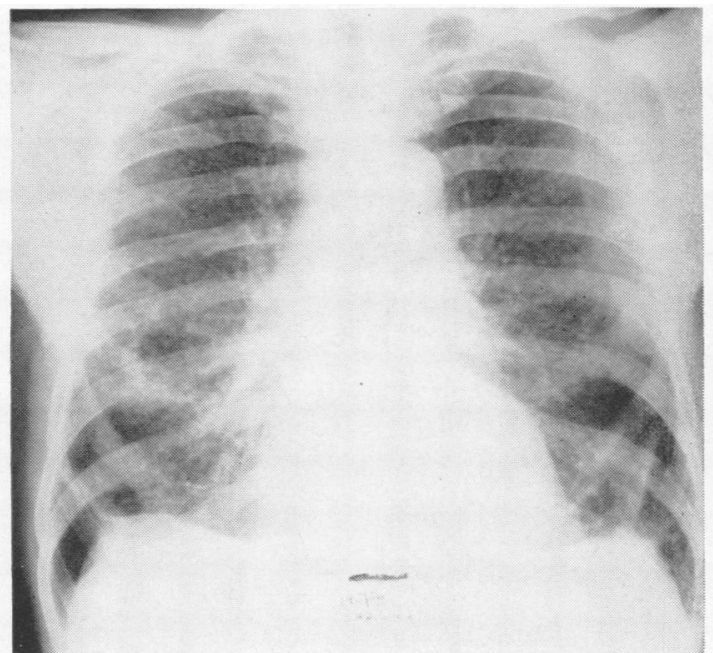

(b) 1962.

subjects were non-secretor and the remaining results are shown in Table III.

Although no association between blood groups and pneumoconiosis was found by Higgins, Oldham, Kilpatrick, Drummond, and Bevan (1963), they recommended that future studies should investigate the variations in the dust dose-response relation to blood groups and pneumoconiosis.

The tuberculous hypothesis is less strongly held 
TABLE I

\begin{tabular}{|c|c|c|c|c|c|c|c|c|}
\hline & $\begin{array}{l}\text { Date } \\
\text { Examined }\end{array}$ & $\begin{array}{l}\text { Weight } \\
\text { (st. lb.) }\end{array}$ & (kg.) & $\begin{array}{l}\text { Height } \\
\text { (ft. in.) }\end{array}$ & $(m)$. & $\begin{array}{l}\text { Blood } \\
\text { Pressure } \\
(\mathrm{mm} . \mathrm{Hg})\end{array}$ & $\begin{array}{l}\text { X-ray } \\
\text { Category }\end{array}$ & $\begin{array}{l}F . E . V \cdot 1 \cdot 0 \\
\text { (litres) }\end{array}$ \\
\hline $\begin{array}{l}X_{1} \\
X_{2}\end{array}$ & $\begin{array}{l}1956 \\
1964 \\
1956 \\
1964\end{array}$ & $\begin{array}{rr}9 & 1 \\
8 & 12 \\
9 & 2 \\
9 & 5\end{array}$ & $\begin{array}{l}57 \\
56 \\
58 \\
59\end{array}$ & $\begin{array}{ll}5 & 3 \frac{1}{2} \\
5 & 3 \frac{1}{2} \\
5 & 4 \\
5 & 4\end{array}$ & $\begin{array}{l}I \cdot 60 \\
I \cdot 60 \\
I \cdot 62 \\
I \cdot 62\end{array}$ & $\begin{array}{l}160 / 110 \\
190 / 120 \\
145 / 90 \\
230 / 130\end{array}$ & $\begin{array}{l}3 \mathbf{A I} /- \\
3 \mathbf{A I} /- \\
3 \mathbf{A I} /- \\
3 \mathbf{A I} /-\end{array}$ & $2 \cdot 9$ \\
\hline
\end{tabular}

TABLE II

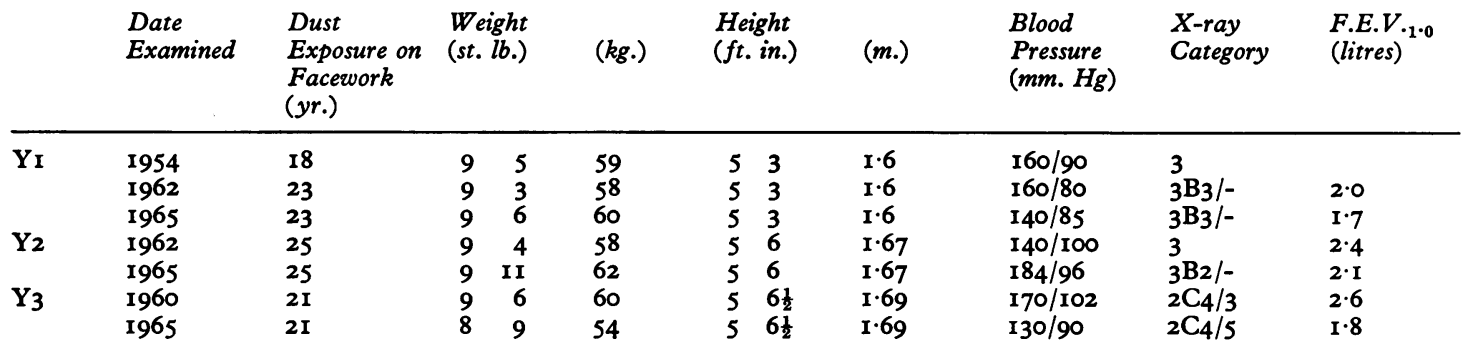

TABLE III

\begin{tabular}{|c|c|c|c|c|c|c|c|}
\hline & $\begin{array}{l}\text { Blood } \\
\text { Groups }\end{array}$ & $\begin{array}{l}A n t i \\
B\end{array}$ & $\begin{array}{l}A n t i \\
A\end{array}$ & $\begin{array}{l}\text { Cells } \\
A B \quad O\end{array}$ & $C D E \subset e$ & $M N$ & $\begin{array}{l}\text { Rose } \\
\text { Waaler }\end{array}$ \\
\hline $\mathbf{X}_{\mathbf{Y}}$ & A & - & + & -+- & +--++ & -+ & Negative \\
\hline $\mathrm{X}_{2}$ & A & - & + & -+- & +--++ & -+ & Negative \\
\hline $\mathbf{Y I}_{\mathbf{I}}$ & $\mathbf{O}$ & - & - & ++- & ++--+ & +- & Negative \\
\hline Y2 & B & + & - & +- & ++-++ & ++ & Negative \\
\hline $\mathbf{Y}_{3}$ & 0 & - & - & ++- & $++-t$ & ++ & Negative \\
\hline
\end{tabular}

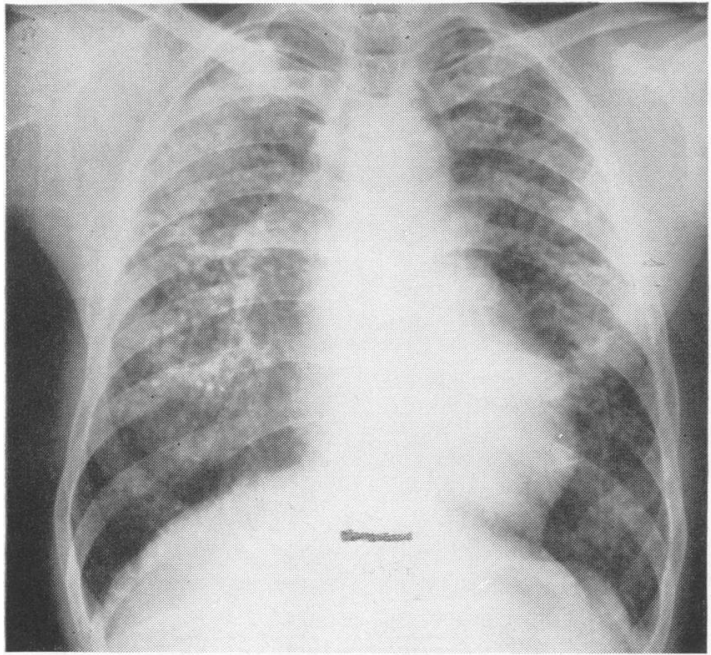

FIG. 3. Chest radiographs twin brother YI, (a) I962;

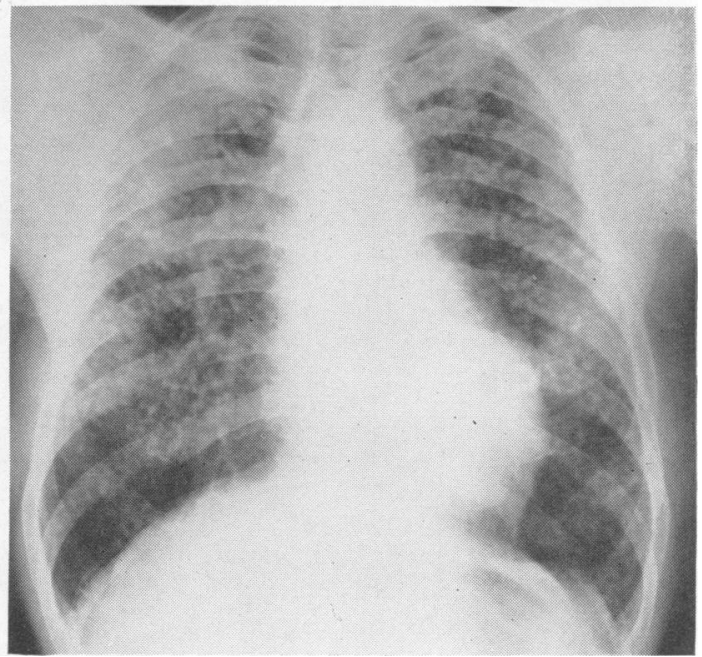

(b) 1964 . 


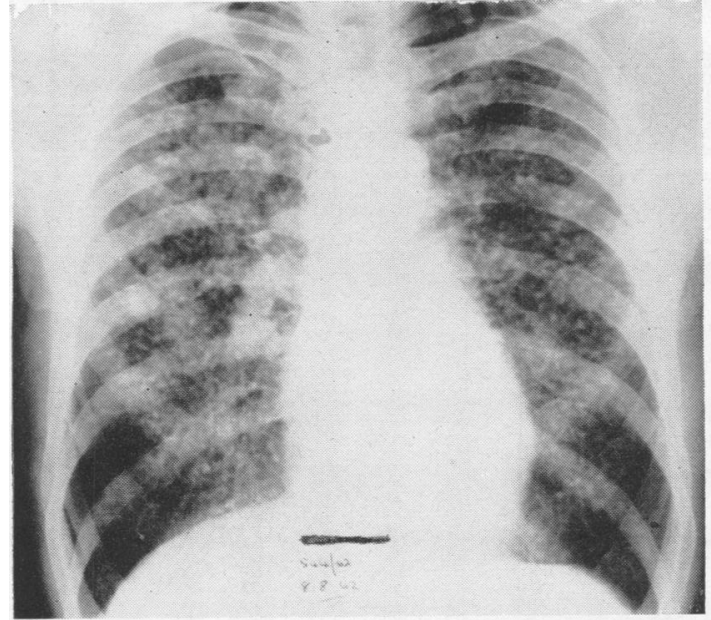

FIG. 4. Chest radiographs twin brother Y2, (a) 1962;

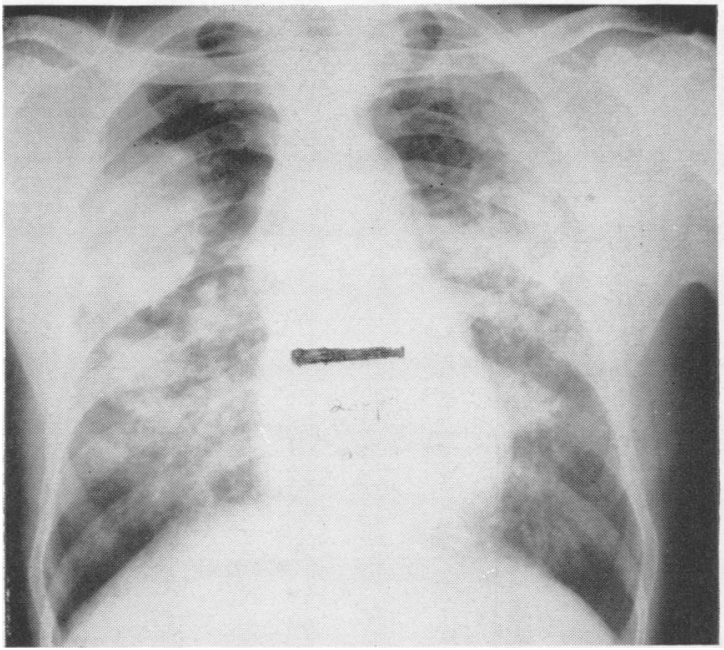

FIG. 5. Chest radiographs younger brother $\mathrm{Y}_{3},(a)$ 1960;

nowadays as an explanation for progressive massive fibrosis so the possible importance of genetic factors should be considered. As twins are very suitable for such an investigation details are given for a monozygotic pair and a dizygotic pair of twins together with the younger brother of the latter.

I am grateful to Dr. J. Watkins-Pitchford, Chief Medical Officer, Ministry of Pensions and National

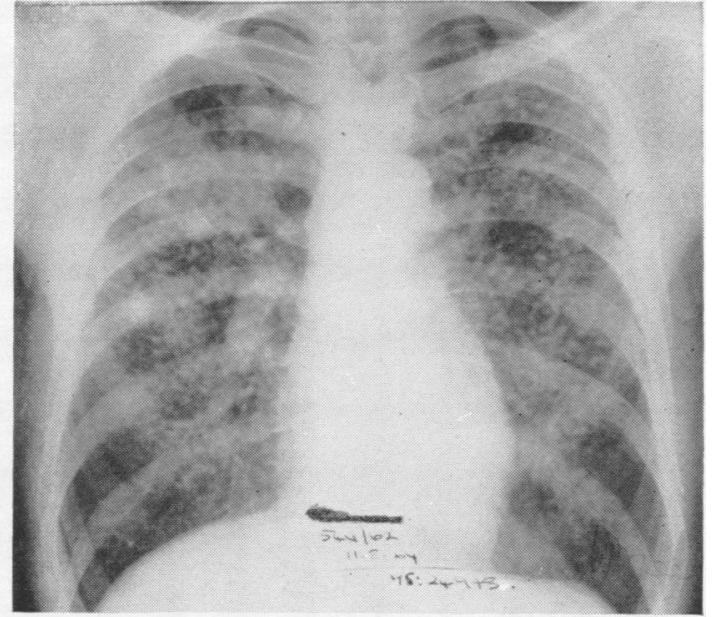

(b) 1964 .

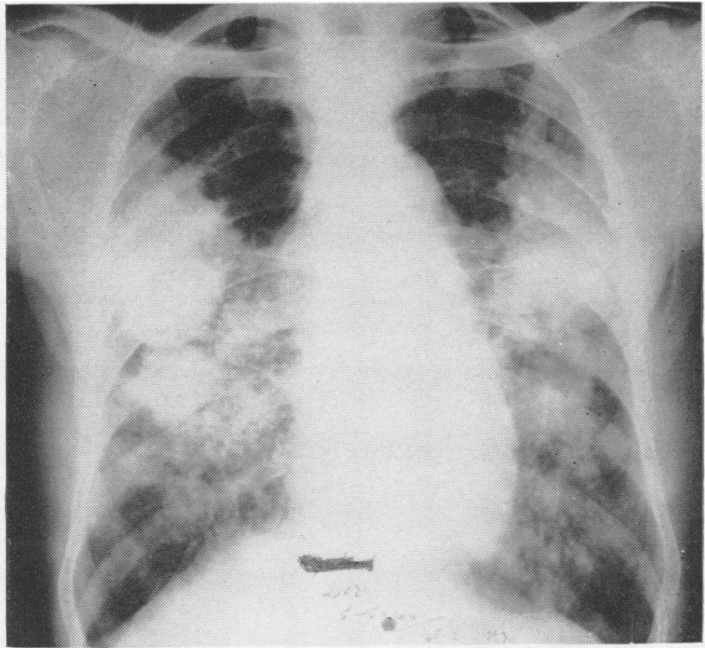

(b) 1964

Insurance, for permission to publish this paper; and to Dr. A. Caplan and Dr. J. C. McVittie for their advice and encouragement.

My thanks are also due to Professor C. A. Green, Bacteriology Department, Royal Victoria Infirmary, Newcastle upon Tyne, and Dr. A. J. Wort, Consultant Pathologist, Stockton and Thornaby Hospitals, for blood grouping and serological tests.

The photographs of the chest radiographs were taken by Kodak Ltd., London. 
REFERENCES

Caplan, A., Payne, R. B., and Withey, J. L. (1962). Thorax, I7, 205.

Higgins, I. T. T., Oldham, P. D., Kilpatrick, G. S., Drummond, R. J., and Bevan, B. (1963). Brit. F. industr. Med., 20, 324.

Sluis Cremer, G. K. (1960). In Proceedings of the Pneumoconiosis Conference, Fohannesburgh, 1959, Ed. A. J. Orenstein, p. 606. Churchill, London.

\section{Addendum}

A report on the necropsy findings in twin $\mathrm{X}_{2}$ is as follows: 'Only a slight amount of simple pneumoconiosis was present in the langs. No progressive massive fibrosis was present. A film of pleural thickening was present over the right lung, most marked in the mid zone. The cause of death was left ventricular failure due to hypertension.'

\section{The April (1966) Issue}

The April (1966) issue contains the following papers:-

The Anaemia of Lead Poisoning: A Review. H. A. WALDRON

Incidence of Hypertension among Lead Workers. A Follow-up Study based on Regular Control over 20 years. KIM CRAMÉr and LENNART DAHLBERG

Blood Lead and Haemoglobin in Lead Absorption. M. K. WILLIAMS

Urinary Coproporphyrin Isomers I and III in Lead Workers and a Control Group. SHAWKIA MEHANI

Trichloroethanol in Trichloroethylene Poisoning. H. MIKISKovÁ and A. MIKISKA

The Toxicity of Paraquat. D. G. Clark, T. F. McElligot, and E. Weston Hurst

Absorption and Excretion of Diquat and Paraquat in Rats. J. W. DANIEL and J. C. GAGE

Experimental Studies on Skin Hazard with 'Versatic' 9-II Acid and its Monoglycidyl and Vinyl

Esters. C. G. Hunter, V. K. BRown, and L. W. FerRigan

Diurnal Variation in Ventilatory Capacity. An Epidemiological Study of Cotton and other

Factory Workers employed on Shift Work. JOAN WALFORD, B. LAMMERS, R. S. F. SchILliNG,

D. vaN DEN HOVEN VAN GENDEREN, and Y. G. VAN DER VeEN

Millworkers' Asthma: Allergic Responses to the Grain Weevil (Sitophilus granarius). J. A. LUNN Miscellanea

Hazy Vision in Amine Plant Operatives. J. Mellerio and R. A. Weale

The Future of an Occupational Health Unit in Khartoum University, The Sudan. MustafA KHOGALI

\section{Book Reviews}

A number of copies are still available and may be obtained from the Publishing Manager, British Medical Association, Tavistock Square, W.C.I, price I8s. $6 d$. 